\title{
Regulation of the levels of health promoting compounds: lupeol, mangiferin and phenolic acids in the pulp and peel of mango fruit: a review
}

\author{
Running title: Regulation of phytochemicals in mango fruit
}

Mekhala D K Vithana $^{\mathrm{a}}$, Zora Singh ${ }^{\mathrm{a}^{*}}$ and Stuart K Johnson ${ }^{\mathrm{a}, \mathrm{b}}$

${ }^{\mathrm{a} C u r t i n}$ Horticulture Research Laboratory, School of Molecular and Life Sciences, Faculty of Science and Engineering, Curtin University, GPO Box U1987, Perth 6845, Western Australia.

${ }^{\mathrm{a}}$ School of Molecular and Life sciences, ${ }^{\mathrm{b}}$ Curtin Health Innovation Research Institute, Faculty of Science and Engineering, Curtin University, GPO Box U1987, Perth 6845, Western Australia.

*Corresponding author (e-mail: Z.Singh@curtin.edu.au; Tel +61892663138; Fax $+61892663063)$

\begin{abstract}
There is a demand for feasible methodologies that can increase/ maintain the levels of health-promoting phytochemicals in horticultural produce, due to strong evidence that these compounds can reduce risk of chronic diseases. Mango (Mangifera indica L.), ranks fifth among the most cultivated fruit crops in the world, is naturally rich in phytochemicals such as lupeol, mangiferin and phenolic acids (eg. gallic acid, chlorogenic acid and vanillic acid). Yet, there is still much scope for up-regulating the

This article has been accepted for publication and undergone full peer review but has not been through the copyediting, typesetting, pagination and proofreading process, which may lead to differences between this version and the Version of Record. Please cite this article as doi: 10.1002/jsfa.9628
\end{abstract}

This article is protected by copyright. All rights reserved. 
levels of these compounds in mango fruit through manipulation of different pre- and postharvest practices that affect their biosynthesis and degradation. The process of ripening, harvest maturity, physical and chemical elicitor treatments such as low temperature stress, methyl jasmonate (MeJA), salicylic acid (SA) and nitric oxide (NO) and the availability of enzyme cofactors $\left(\mathrm{Mg}^{2+}, \mathrm{Mn}^{2+}\right.$ and $\left.\mathrm{Fe}^{2+}\right)$ required in terpenoid biosynthesis were identified as potential determinants of the concentration of health-promoting compounds in mango fruit. The effectiveness of these pre- and postharvest approaches in regulating the levels of lupeol, mangiferin and phenolic acids in the pulp and peel of mango fruit will be discussed. In general spray application of $0.2 \% \mathrm{FeSO}_{4} 30 \mathrm{~d}$ before harvest, harvest at sprung stage,storage of mature green fruit at $5{ }^{\circ} \mathrm{C}$ for $12 \mathrm{~d}$ prior to ripening, fumigation of mature green fruit with $10^{-5} \mathrm{M}$ and/or $10^{-4} \mathrm{M}$ MeJA for $24 \mathrm{~h}$ or 20 and/or $40 \mu \mathrm{L} \mathrm{L}^{-1} \mathrm{NO}$ for $2 \mathrm{~h}$ upregulate the levels of lupeol, mangiferin and phenolic acids in pulp and peel of ripe mango fruit.

KEYWORDS: Mangifera indica L.; health promoting compounds; regulation; preand postharvest factors

\section{INTRODUCTION}

Mango (Mangifera indica L.) has been among the most favoured fruit in the world since ancient history due to its rich flavour and nutritional value. In the recent past, the importance of mango fruit as a health promoting commodity has been significantly highlighted. ${ }^{1}$ Mango fruit is renowned for its rich content of health-promoting compounds which can reduce the risk of several degenerative diseases including cardiovascular diseases and different types of cancer. ${ }^{2}$ Among the major fruit crops 
cultivated worldwide mango ranks at fifth position in total production (over 42.1 million Mt including mangosteen and guava) and it is grown over an area of 5.4 million ha in nearly 100 countries in the world (FAOSTAT, www.fao.org/faostat/en, 2017). The world mango production is expanding steadily (FAOSTAT, www.fao.org/faostat/en, 2017). Thus, value addition to this fruit of choice by increasing the concentrations of health-promoting compounds would possibly provide a noteworthy contribution to the health prospects of its consumers worldwide. To achieve this, a thorough understanding is necessary of the biosynthetic pathways of the desired phytochemicals as well as different pre- and postharvest factors that may affect the regulation of their levels.

In the past few decades a considerable amount of literature on bioactive compounds present in the pulp, peel and seed of mango fruit and their health benefits had been reviewed. ${ }^{1-3}$ However, none of these details the current/ potential pre- and postharvest approaches in regulating the levels of these compounds in this fruit of choice. Thus, to the best of our knowledge, this review for the first time deliberates various pre- and postharvest approaches in regulating the levels of the healthpromoting bioactive compounds in mango fruit. Further, this review focuses on health promoting terpenoid: lupeol and phenolic compounds: mangiferin and phenolic acids, their biosynthesis, health benefits; pre- and postharvest factors that could influence their concentrations and the present understanding of different methods that can be employed to up-regulate/ maintain the concentrations of these compounds in ripe mango fruit which is of utmost importance for the health-conscious markets in trend.

MAJOR HEALTH-PROMOTING SECONDARY COMPOUNDS PRESENT IN MANGO FRUIT AND THEIR RELATIVE ABUNDANCE IN PULP AND PEEL 
A number of studies have revealed that virtually every part of mango tree, viz. pulp, peel, and seed of mango fruit, extracts from bark, leaves and flowers are a good source of beneficial phytochemicals. ${ }^{1,4,5,6}$ However, this review only focuses on the pulp and peel of the fruit.

Lupeol, mangiferin, gallic acid, chlorogenic acid, vanillic acid, caffeic acid, ferulic acid, protocatechuic acid, anthocyanins, quercetin and kaempferol, are among the secondary metabolites present in mango fruit with significant beneficial bioactive properties for humans. ${ }^{2,7,8,9}$ However, the concentrations of these health-promoting compounds present in mango vary in different parts of the fruit such as the pulp and the peel. ${ }^{2}$ For example, the concentration of lupeol in 'Ataulfo' mango was 1-4 times more in the peel than pulp, ${ }^{10}$ whilst it was 1-40 times more in North Indian mangoes depending on the cultivar. ${ }^{11}$ In Australian mango cultivars, the level of lupeol was about 4 and 1.4 times more in the peel than pulp in 'Kensington Pride' and 'R2E2' respectively. ${ }^{9}$ Similarly, the the level of mangiferin in the peel was approximately 15 and 5 times higher than the pulp in 'Kensington Pride' and 'R2E2' respectively, 9 whilst it was significantly higher in the peel than pulp in 'Ataulfo' ${ }^{10}$ and North Indian mango cultivars as well. ${ }^{11}$ The levels of gallic, chlorogenic, vanillic, ferulic and caffeic acids in the peel of 'Kensington Pride' mango were around 20, 2, 10, 6, and 7 folds higher than pulp respectively, and were $25,3,20,30$ and 5 folds higher in 'R2E2' mango respectively. ${ }^{9}$

Overall, the concentrations of major health promoting phytochemicals present in the peel of mango fruit are several folds higher than the pulp regardless of the variety. Thus, mango peel; a major by-product of mango juice production facilities, can also be considered as a good source of bioactive compounds that can be used in food, pharmaceutical and nutraceutical industries. ${ }^{3,4}$ 


\section{HEALTH-BENEFITS OF MAJOR SECONDARY PHYTOCHEMICALS PRESENT IN MANGO FRUIT}

A number of studies have revealed several health benefits of major phytochemicals present in mango fruit (Table 1).

\section{Lupeol}

Lupeol is a naturally occurring pentacyclic triterpine (Fig. 1) that present in various plant parts in different concentrations. Mango pulp, grape, hazelnut, olive oil, carrot root, cucumber, soybean and cabbage are found to be rich sources of this compound. ${ }^{8}$, 12,13

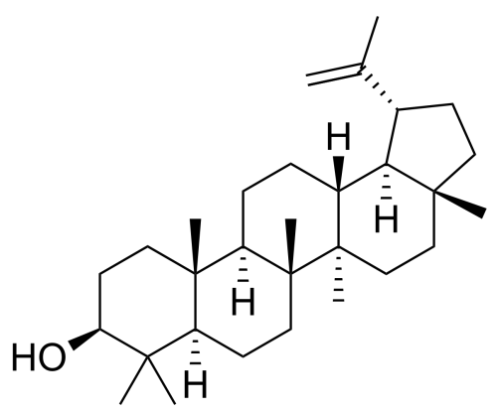

Fig. 1 The chemical structure of lupeol (Source: https://www.sigmaaldrich.com)

The ability of lupeol to selectively target diseased human cells is well known. ${ }^{8}$ Lupeol is also known for its ability to interact with multiple molecular targets to help control carcinogenesis. ${ }^{12}$ A study on mouse prostrate cells demonstrated that lupeol could prevent development of cancer cells and eliminate existing cancer cells through induction of apoptosis. ${ }^{14}$ Similar results were found in the induction of apoptosis in human prostate cancer cells. ${ }^{14}$ Further, its efficacy in controlling colorectal cancer 
cells, ${ }^{15}$ bone marrow cancer cells ${ }^{14}$ and cutaneous melanoma ${ }^{13}$ have also been reported.

\section{Mechanisms of action of lupeol against cancer}

Lupeol has shown its potential in controlling cancer cells via different mechanisms of actions (Gallo and Sarachine, 2009). ${ }^{12}$ Lupeol is considered as a potential anticancer agent in tumors due to its ability to inhibit farnesyltransferase enzyme (Sturn et al., 1996). ${ }^{16}$ Its ability in inhibiting topoisomerase II enzyme (topo II) was another earliest recognized cancer controlling mechanism. Topo II enzyme is responsible for the conversion of supercoiled double stranded DNA to relaxed DNA by catalyzing a transient break (Moriarity et al., 1998). ${ }^{17}$ Lupeol was found to be capable of inhibiting this conversion in supercoiled plasmid DNA by selectively inhibiting topo II catalytic reaction due to its ability to interfere with binding of topo II to DNA (Wada et al., 2001). ${ }^{18}$

Besides the capability of lupeol to inhibit the lyase activity of DNA polymerase $\beta$ at an $\mathrm{IC}_{50}$ value (concentration that inhibited cell growth by 50\%) of 6.4 $\mu \mathrm{M}$ was identified as another mechanism of action against cancer (Chaturvedula et al., 2004b). ${ }^{19}$

Lupeol-induced apoptosis of cancer cells has also gained much attention (Gallo and Sarachine, 2009). ${ }^{12}$ Lupeol has demonstrated to cause apoptosis in human promyelotic leukemia HL 60 cells (Aratanechemuge et al., 2004), ${ }^{20}$ human prostate cancer cell lines LNCaP and CWR22Rv1 (Saleem et al., 2005a), ${ }^{21}$ AsPC1 human pancreatic adenocarcinoma cells (Saleem et al., 2005b), ${ }^{22}$ human melanoma cells 451Lu and WM35 (Saleem et al., 2008), ${ }^{23}$ human epidermoid carcinoma A431 cells (Prasad et al., 2009) ${ }^{24}$ as well as hepatocellular carcinoma SMMC7721 cell line 
(Zhang et al. 2009) ${ }^{25}$ among others. The mode of action of lupeol in inducing apoptosis slightly defers with the type of cancer (Gallo and Sarachine, 2009). ${ }^{12}$

In addition to its cancer preventive potential lupeol has also demonstrated cardioprotective effects. It has shown protective effects against in vitro LDL oxidation (Andrikopulos et al., 2003), ${ }^{26}$ cardiac disorder and consequent cardiovascular diseases (Saleem et al., 2003) ${ }^{27}$ and cardiac oxidative injury (Sudharsan et al., 2005). ${ }^{28}$

Similar to cancer and cardiovascular disease control, lupeol has exhibited several anti-inflammatory mechanisms of action. Reducing neutrophils in the inflamed tissues (Fernandez et al., 2001), ${ }^{29}$ decreasing IL-4 (interleukin 4) production by Th2 cells (T-helper type 2) (Bani et al., 2006), ${ }^{30}$ reducing eosinophils infiltration and Th2 associated cytokines (Il-4, IL-5, IL-3) (Vasconcelos et al., 2008), ${ }^{31}$ reducing LPSinduced IL-6 secretion (Ding et al., 2009) ${ }^{32}$ are among its anti-inflammatory modes of action. Moreover,various in vitro and preclinical animal studies suggest that lupeol has a potential to act as an, anti-invasive, anti-angiogenic and cholesterol lowering agent. Furthermore, it has shown its capability as an anti-arthritic, anti-microbial, antiprotozoal and anti- diabetic agent. ${ }^{33}$

\section{Mangiferin}

Mangiferin (C-2- $\beta$-D-glucopyranosyl-1, 3, 6, 7-tetrahydroxyxanthone) classified under flavonoid group of polyphenols is a glucosyl xanthone present in mango fruit. ${ }^{1}$ It has been found to possess a wide array of pharmacological potentials such as: antioxidant, anticancer, antimicrobial, antiatherosclerotic, antiallergenic, antiinflammatory and analgestic among many others. ${ }^{2}$ Many studies have revealed that 
the majority of the health beneficial properties of mango extract have been ascribed to this compound. $1,34,35,36$<smiles>O=c1c2cc(O)c(O)cc2oc2cc(O)c(O)c(O)c12</smiles>

Fig. 2 The chemical structure of mangiferin (Source: https://www.sigmaaldrich.com)

Mangiferin has iron-complexing abilities and thus can be used to reduce ironinduced oxidative damage. ${ }^{35,36}$ Furthermore, it has a confirmed ability to reduce the progression of degenerative diseases including Parkinson's disease, in which oxidative stress plays a crucial role. ${ }^{37}$ Moreover, it has shown its potential to ameliorate the oxidative stress found in neurodegenerative disorders due to its ability to pass through blood-brain barrier. ${ }^{34}$ It has been suggested that mangiferin also protects erythrocytes and red blood cells from reactive oxygen species production. ${ }^{38,} 39$ Mangiferin was found to significantly reduce plasma total cholesterol, triglycerides and low density lipoprotein (LDL) in diabetic rats. ${ }^{40}$

Its ability in reducing blood glucose level by inhibiting the glucose absorption from the intestine was also reported. ${ }^{41,42}$ Besides, mangiferin could inhibit body weight gain in experimental rats showing a potential in its usage in designing novel food products for special dietary needs for obese people. ${ }^{43}$

\section{Phenolic acids}

Mango fruit is rich in several phenolic acids which are known for their therapeutic potential. ${ }^{1,7}$ Gallic acid, chlorogenic acid and vanillic acid are among the major 
phenolic acids in mango fruit, whilst protocatechuic acid, ferulic and caffeic acids also present in lower concentrations in both pulp and peel. ${ }^{7,9}$

Phenolic acids are aromatic secondary plant metabolites which derived from two parent structures called hydroxybenzoic acid (Fig. 4) and hydroxycinnamic acid (Fig. 5). ${ }^{44}$ Thus, they are basically divided into two groups, viz. hydroxybenzoic acids and cinnamic acids. Gallic acid, protocatechuic acid and vanillic acid are among the major hydroxybenzoic acids whilst, caffeic acid and ferulic acid are classified as cinnamic acids. Chlorogenic acid which possesses significant health benefits is an ester of caffeic acid and quinic acid.

Gallic acid<smiles>O=C(O)c1cc(O)c(O)c(O)c1</smiles>

Chlorogenic acid<smiles>O=C(/C=C/c1ccc(O)c(O)c1)OC1CC2(O)CC(O)C(O)CC1C2O</smiles>

Vanillic acid<smiles>COc1cc(C(=O)O)ccc1O</smiles>

Protocatechuic acid<smiles>O=C(O)c1ccc(O)c(O)c1</smiles> 
Ferulic acid<smiles>COc1cc(/C=C/C(=O)O)ccc1O</smiles>

Caffeic acid<smiles>O=C(O)/C=C/c1ccc(O)c(O)c1</smiles>

\footnotetext{
Fig. 3 Phenolic acids present in mango fruit ${ }^{7,9}$

(Source: https://www.sigmaaldrich.com)
}<smiles>O=C(O)c1cccc(O)c1</smiles>

Fig. 4 Hydroxybenzoic acid<smiles>O=C(O)/C=C/c1ccc(O)cc1</smiles>

Fig. 5 Hydroxycinnamic acid

Gallic acid (3, 4, 5-trihydroxybenzoic acid) was identified as one of the major phenolic acids present in mango fruit. ${ }^{7,9,45}$ It has a strong antioxidant potential in emulsion or lipid systems. ${ }^{46,47}$ Gallic acid has demonstrated its potential for inhibiting carcinogenesis in several animal models and in in vitro human and animal cancer cell lines. ${ }^{48}$ Ho et al ${ }^{49}$ suggested that gallic acid can be considered as a potential agent to treat gastric cancer, whilst Chen et al ${ }^{50}$ suggested its potential to be developed into an anti-prostate cancer drug. In cell culture studies, gallic acid has shown a similar potential in controlling human leukaemia, ${ }^{51}$ bone cancer, ${ }^{52}$ breast cancer ${ }^{53}$ and lung 
cancer. ${ }^{54}$ In several studies, this compound has been identified as the principle constituent in plant extracts that cause growth inhibition and apoptotic death of DU145 human prostate carcinoma cells. ${ }^{50,55}$ Thus, Chen et al ${ }^{50}$ suggested that gallic acid has the potential to be developed into an anti-prostate cancer drug. Moreover, Inoue et al 56 reported that gallic acid was cytotoxic against all cancer cell lines that they examined.

Based on several in vivo and in vitro studies; chlorogenic acid was also found to be capable of exhibiting important antioxidant and anti-carcinogenic activities. ${ }^{57}$ It has demonstrated its ability in protecting healthy cells against apoptosis induced by oxidative stress by suppressing reactive oxygen species. ${ }^{58}$ Further, Cho et al ${ }^{59}$ reported that chlorogenic acid possesses anti-obesity property and could improve lipid metabolism in obese mice. The ability of chlorogenic acid in suppressing asthma, ${ }^{60}$ lipopolysaccharide-induced acute lung injury in mice, ${ }^{61}$ liver inflammation and fibrosis, ${ }^{62}$ diabetes ${ }^{63}$ and ischemia/reperfusion injury in rat liver ${ }^{64}$ have also been reported.

Vanillic acid (4-hydroxy-3-methoxy benzoic acid) has also shown several beneficial properties. ${ }^{65}$ Kumar et al ${ }^{66}$ stated that, this compound was capable of managing blood pressure in rats. The protective role of vanillic acid in rats with chemically induced cardiovascular dysfunction as a result of free radical scavenging and anti-inflammatory properties was also demonstrated. ${ }^{67}$ Furthermore, vanillic acid can be used in combination with cancer chemotherapy. ${ }^{68}$

Ferulic acid (4-hydroxy-3-methoxycinnamic acid) is also endowed with many physiological functions including antioxidant, antimicrobial, anti-inflammatory, antithrombosis, and anti-cancer activities. It also plays a protective role against coronary diseases and lowers cholesterol in animal studies. ${ }^{69}$ Kanski et al ${ }^{70}$ reported that 
ferulic acid could greatly reduce the free radical damage in neuronal cell systems and therefore; possesses a significant therapeutic potential against neurodegenerative disorders such as Alzheimer disease.

Caffeic acid (3, 4-dihydroxycinnamic acid) is another phenolic acid known for its strong antioxidant potential ${ }^{71}$ and is also recognized as an effective anti-diabetic agent in rats. ${ }^{72}$ Moreover, caffeic acid has exhibited its ability in protecting pBR322 plasmid DNA against the mutagenic and toxic effects of UV radiation and hydrogen peroxide $\left(\mathrm{H}_{2} \mathrm{O}_{2}\right) .{ }^{73}$ 
Table 1: The health benefits of major phytochemicals present in mango fruit.

Phytochemicals Health benefits References

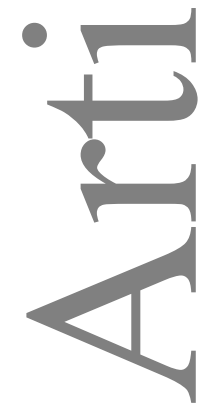

Lupeol Selectively target diseased human cells

Anti- carcinogenic

Control prostate cancer cells

Control colorectal cancer cells

Control cutaneous melanoma

Anti-inflammatory, anti-invasive, anti-angiogenic, anti-arthritic, anti-microbial, anti protozoal, anti-diabetic and cholesterol lowering agent

Reduce iron-induced oxidative damage

Reduce the progression of Parkinson's disease

Ameliorate oxidative stress found in neurodegenerative disorders

Protect erythrocites and red blood cells from reactive oxygen species production
Saleem, 2009

Gallo and Sarachine, 2009

Prasad et al., 2008

Tarapore et al., 2013

Syed and Mukhtar, 2011

Siddique and Saleem, 2011

Puccio and Koenig, 2002;

Halliwell and Gutteridge, 1986

Halliwell, 2006

Martinez et al., 2001

Pawlak et al., 1998; Rodriguez et

This article is protected by copyright. All rights reserved. 


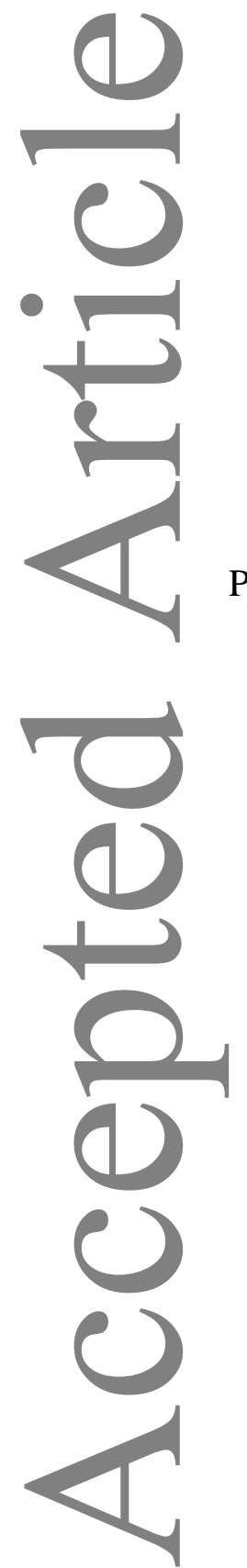

Reduce plasma cholesterol, triglycerides and low density lipoprotein

Reduce blood glucose level

Inhibit body weight gain

Phenolic acids

Gallic acid

Strong antioxidant in lipid systems

Anti- carcinogenic

Control gastric cancer

Control prostate cancer

Control leukaemia

Control bone cancer

Control lung cancer al., 2006)

Muruganadan et al., 2005

Yoshikawa et al., 2001;

Aderibrigbe et al., 2001

Yoshimia et al., 2001

Yen et al, 2002; Madsen and

Bertelsen, 1995

Verma et al., 2013

Ho et al., 2013

Chen et al., 2009; Veluri et al., 2006

Reddy et al., 2012

Liao et al., 2012

Ji et al., 2009

This article is protected by copyright. All rights reserved. 
Protect cells against oxidative stress

Anti-obesity property

Suppress asthma

Reduce lipopolysaccharide induced acute lung injury

Suppress liver inflammation and fibrosis

\section{Control diabetes}

Control ischemia/ reperfusion injury

Manage blood pressure

Free radical scavenging and anti-inflammatory

Anti-carcinogenic
Li et al., 2012

Cho et al., 2010

Kim et al., 2010

Zhang et al., 2010

Shi et al., 2012

Ong et al., 2013

Yun et al., 2012

Kumar et al., 2014

Prince et al., 2011

Sindhu et al., 2015

This article is protected by copyright. All rights reserved. 
Ferulic acid

Protective against coronary diseases and reduce cholesterol

Reduce free radical damage and control Alzheimer disease

Strong antioxidant

Anti-diabetic

Protect pBR322 plasmid DNA against UV and $\mathrm{H}_{2} \mathrm{O}_{2}$
Ou and Kwok, 2004

Kanski et al., 2002

Gulcin, 2006

Jung et al., 2006

Sevgi et al., 2015

This article is protected by copyright. All rights reserved. 


\section{FACTORS AFFECTING THE LEVELS OF LUPEOL AND PHENOLIC COMPOUNDS IN MANGO FRUIT}

The levels of lupeol and phenolic compounds in mango fruit are influenced by a number of pre- and postharvest factors (Table 2).

\section{Effect of the genotype}

Mango has a wide range of genetic variation. ${ }^{74}$ There are hundreds of mango cultivars with distinct visual diversity in shape, size and colour and internal differences in flavour and the nutrient composition. ${ }^{75}$ In addition to these differences, a significant diversity in the concentrations of bioactive compounds has also been reported in mango fruit.

Srivastava et al ${ }^{11}$ reported a significant variation in the concentration of lupeol in the pulp and peel among four Indian mango cultivars: 'Bombay Green', 'Dashehari', 'Langra' and 'Chausa'. A significantly higher concentration of lupeol was found in both the pulp and peel of 'Dashehari' mango fruit followed by 'Langra', whilst a significantly lower amount was noted in the fruit of 'Chausa'. Similarly, RuizMontanez et al ${ }^{10}$ reported that the concentration of lupeol was influenced by the cultivar in a study carried out using 'Ataulfo' and native mango fruit. The level of lupeol in ripe fruit was higher in both the pulp and peel of 'R2E2' mango fruit than 'Kensington Pride'. 9

The concentration of mangiferin was significantly different in four cultivars of Brazilian mangoes; recording $2.9 \mathrm{mg} \mathrm{kg}^{-1}$ in 'Haden', $2.2 \mathrm{mg} \mathrm{kg}^{-1}$ in 'Tommy Atkins', $12.4 \mathrm{mg} \mathrm{kg}^{-1}$ in 'Uba' on dry weight basis, whilst it was not detected in the fruit of cultivar 'Palmer'. ${ }^{76}$ Srivastava et al ${ }^{11}$ reported that the concentration of mangiferin 
was the highest in the pulp of 'Bombay Green' mango fruit compared to 'Dashehari', 'Langra' and 'Chausa', while it was the highest in the peel of 'Langra' fruit compared to other three. Similar observations were recorded in the concentrations of flavonol- $O$ glycosides in these cultivars, thus providing evidence of the genotypic influence on the concentration of secondary metabolites. ${ }^{76}$ Further, the concentration of mangiferin in the peel ranged from $300.0-1300 \mathrm{mg} \mathrm{kg}^{-1}$ in dry weight basis among 'Chok Anan', 'Tommy Atkins', 'Maha Chanock' and 'Kaew' mango fruit whilst, significantly lower concentrations in 'Haden' and 'Kent'. ${ }^{77}$ The level of mangiferin was more in the ripe pulp of 'Kensington Pride' mango fruit compared to 'R2E2', whereas the opposite was observed in the ripe peel. ${ }^{9}$

A significantly high concentration of total phenolics was noted in the pulp of 'Ataulfo' mango fruit $\left\{166.7 \mathrm{mg}\right.$ gallic acid equivalent (GAE) $\left.100 \mathrm{~g}^{-1}\right\}$, whilst the

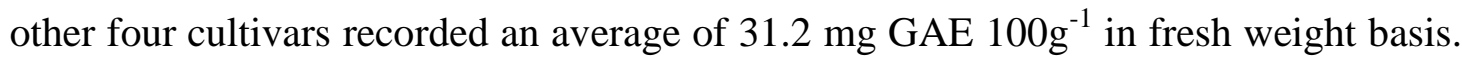
78 The major phenolic acids identified in 'Ataulfo' mango fruit were chlorogenic acid, gallic acid, vanillic acid in the order of relative abundance, ${ }^{7}$ whereas, gallic acid was the major phenolic acid present in the pulp of 'Tommy Atkins' ${ }^{45}$ and both the pulp and peel of 'Kensington Pride' and 'R2E2' mango fruit. ${ }^{9}$

According to Ma et al, ${ }^{79}$ the concentration of total phenols in the pulp varied from 8.8 to $193.4 \mathrm{mg}$ GAE $100 \mathrm{~g}^{-1}$ in fresh weight basis among eight cultivars of mango fruit they studied, 'Tainong' having the highest and 'Guifei' the lowest. The total flavonoid content of the pulp was also the highest in 'Tainong' mango fruit (90.9 $\mathrm{mg}$ rutin $100 \mathrm{~g}^{-1}$ ), whilst the fruit of 'Guifei' having the lowest content (6.28 rutin 100 $\left.\mathrm{g}^{-1}\right)$.The total phenol concentrations in the pulp and peel of 'Kensington Pride' mango fruit were higher than 'R2E2' mango fruit. ${ }^{9} \mathrm{Li}$ et al ${ }^{80}$ reported that the concentrations 
of total polyphenols and total flavonoids were significantly higher in green peel mango fruit compared to red peel or yellow peel mangoes of 11 different cultivars.

\section{Effect of the degree of ripeness}

The degree of ripeness has shown a marked influence in the concentration of bioactive compounds in mango fruit. The major phenolic compounds in 'Ataulfo' mango pulp tended to increase with the advancement of fruit ripening. ${ }^{81}$ The highest concentration of total phenols was recorded in the pulp of 'Ataulfo' mango fruit harvested at 20-30\% and $70-80 \%$ yellow surface stages when compared with the fruit harvested at $0-10 \%$ and $100 \%$ yellow surface stages. ${ }^{81}$ Similarly, the concentrations of chlorogenic acid and vanillic acid were significantly high in the fruit harvested at $71-100 \%$ yellow peel stage. $^{7}$

According to Ruiz-Montanez et al, ${ }^{10}$ significantly higher concentrations of lupeol and mangiferin were noted in the pulp and peel of 'Ataulfo' mango fruit harvested at consumption maturity stage when compared with the fruit harvested at physiological maturity stage. The concentration of lupeol in the peel of 'Dashehari' mango fruit has also shown a significant increase during ripening. ${ }^{11}$

A significant difference in the levels of lupeol, maniferin and phenolic acids were observed in ripe 'Kensington Pride' mango fruit which were harvested at four different maturity stages; mature green, sprung stage, half ripe and tree ripe. The ripe mango fruit harvested at sprung stage recorded the highest levels of lupeol, mangiferin, vanillic acid, ferulic acid and caffeic acid and gallic acid, chlorogenic acid. ${ }^{82}$ Therefore, delaying the harvest of mango fruit until sprung stage could be considered as a promising strategy to obtain ripe mangoes with higher levels of health promoting compounds and thus, improved health benefits. 


\section{Effect of low temperature storage}

Although many studies have investigated the effect of low temperature storage on the content of bioactive compounds in different fruit and vegetables, published data are rather limited on its influence on the levels of terpenoids and phenolic healthpromoting compounds in mango fruit.

The exposure of fruit and vegetables to low temperature stress during storage is considered as a physical elicitor treatment which triggers the production of desired phenolic compounds. ${ }^{83}$ The biosynthetic pathways of both terpenoids and phenols are activated after an elicitor treatment by inducing the activity of the enzyme, phenylalanine ammonia-lyase (PAL). ${ }^{84,85}$

According to Vithana et al, ${ }^{86}$ the concentrations of lupeol in pulp and peel and chlorogenic and caffeic acids in the pulp were significantly higher in Kensington Pride mango fruit stored at $5{ }^{\circ} \mathrm{C}$ than $13{ }^{\circ} \mathrm{C}$, whereas mangiferin, gallic, chlorogenic, vanillic, ferulic, and caffeic acids, and total phenols in the peel were significantly higher when stored at $13{ }^{\circ} \mathrm{C}$. Another study revealed that the total phenols concentration continued to increase in the pulp of tree ripe 'Irwin' mango fruit stored for $20 \mathrm{~d}$ at $5{ }^{\circ} \mathrm{C} .{ }^{87}$ Storage of mango fruit at chilling temperature $\left(5^{\circ} \mathrm{C}\right)$ for $12 \mathrm{~d}$ prior to ripening at room temperature could therefore be considered as a simple and practical tool to increase the level of lupeol in ripe mango fruit. On the whole, subjecting mature green mango fruit to low temperature stress as a physical elicitor treatment could be considered as a feasible technique to improve the levels of health promoting phytochemicals in the ripe fruit. ${ }^{86,87}$

Effect of climate, soil composition and the geographical location of cultivation

This article is protected by copyright. All rights reserved. 
Effect of climatic and soil related factors on the concentrations of health-promoting compounds in mango fruit are rather scanty. According to Manthey and PerkinsVeazie, ${ }^{78}$ the country of origin with differences in soil and climate had a significant influence on the concentration of total phenols in five different cultivars of mango fruit grown in four different countries. Moreover, Palafox-Carlos et al. ${ }^{81}$ reported that, the concentrations of phenolic compounds present in 'Ataulfo' mango fruit grown in Tepic, Nayarit, Mexico were different from those grown in Chiapas State, Mexico. ${ }^{88}$ However, drawing major conclusions from published research on the effect of climate and location on the content of bioactive compounds in fruit is rather difficult due to inconclusive findings. The magnitude of the effect of these factors on the concentration of health-promoting compounds is possibly dependent on the type of the fruit and type of the compound.

\section{Effect of postharvest heat treatment}

To comply with the quarantine requirements of the importing countries exposure of mango fruit to thermal quarantine treatments such as hot water treatment have been practice. However, this might affect the concentrations of bioactive compounds in the treated mango fruit. The concentrations of gallic acid, gallotannins and total soluble phenolics in mature green 'Tommy Atkins' mango fruit were decreased within $2 \mathrm{~h}$ of hot water treatment $\left(46.1{ }^{\circ} \mathrm{C}, 110 \mathrm{~min}\right)$ compared to the untreated fruit and the fruit subjected hot water treatment for $70 \mathrm{~min}$. However, when these fruit were stored for 4 days, the concentration of total soluble phenolics in all hot water-treated fruit decreased regardless of the duration of treatment (70 $\mathrm{min}$ or $110 \mathrm{~min}$ ). Whereas only slight differences were observed in gallic acid and gallotannin concentrations compared to the untreated control. ${ }^{89}$ 
Similarly, the concentrations of gallic acid and several hydrolysable tannins in the pulp of 'Tommy Atkins' mango fruit subjected to hot water treatment $\left(46^{\circ} \mathrm{C}\right.$ for $75 \mathrm{~min}$ ) prior to storage for 2 weeks at $10{ }^{\circ} \mathrm{C}$ under controlled atmospheric conditions comprising of $3 \% \mathrm{O}_{2}+97 \% \mathrm{~N}_{2}$ or $3 \% \mathrm{O} 2+10 \% \mathrm{CO}_{2}+87 \% \mathrm{~N}_{2}$ were unaffected by the hot water treatment, while total polyphenolics decreased throughout fruit ripening, regardless of hot water treatment or storage atmosphere. ${ }^{45}$

This article is protected by copyright. All rights reserved. 
Table 2: Impact of pre- and postharvest factors and treatments on lupeol and phenolic contents of mango fruit

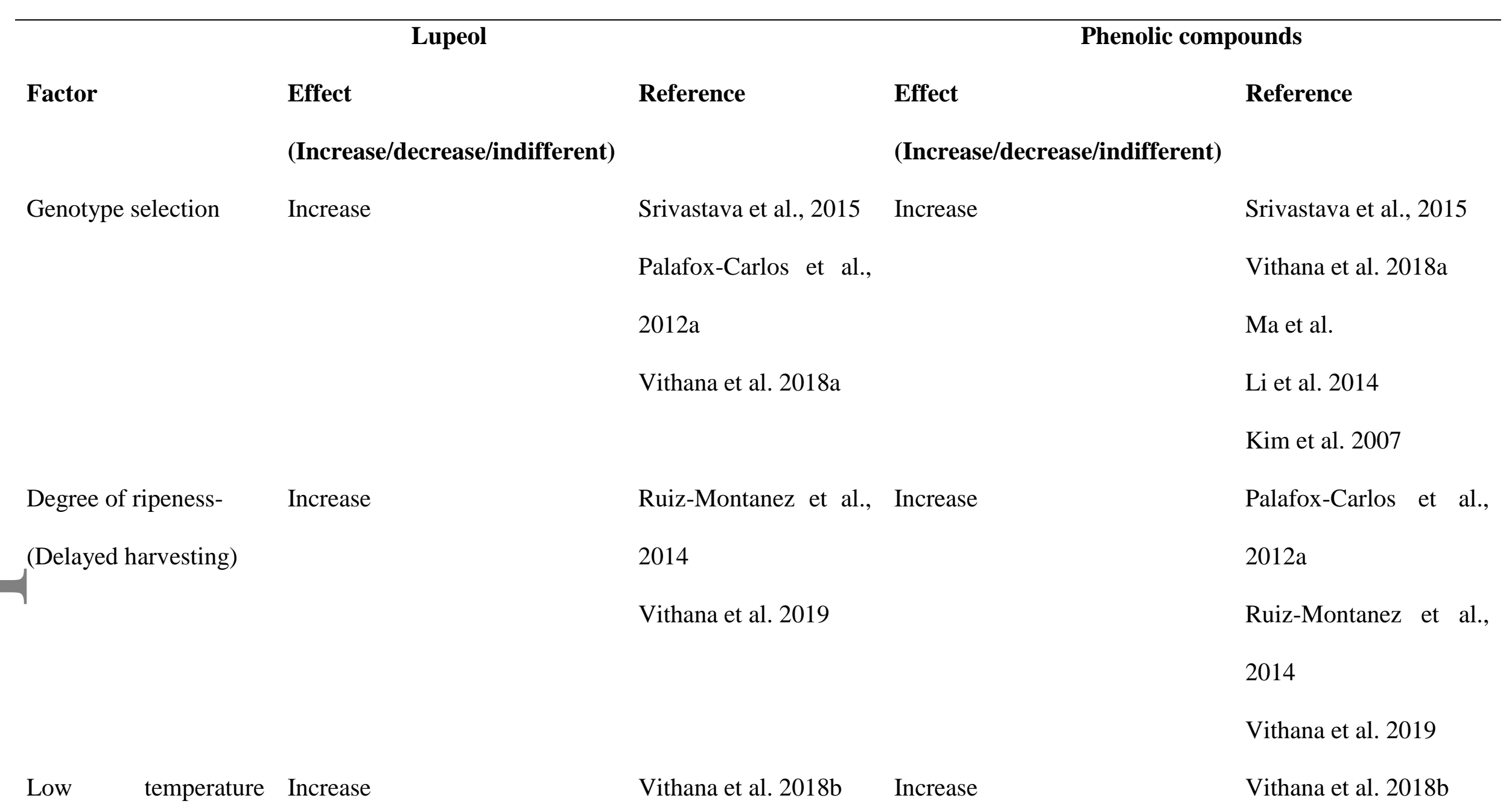

This article is protected by copyright. All rights reserved. 


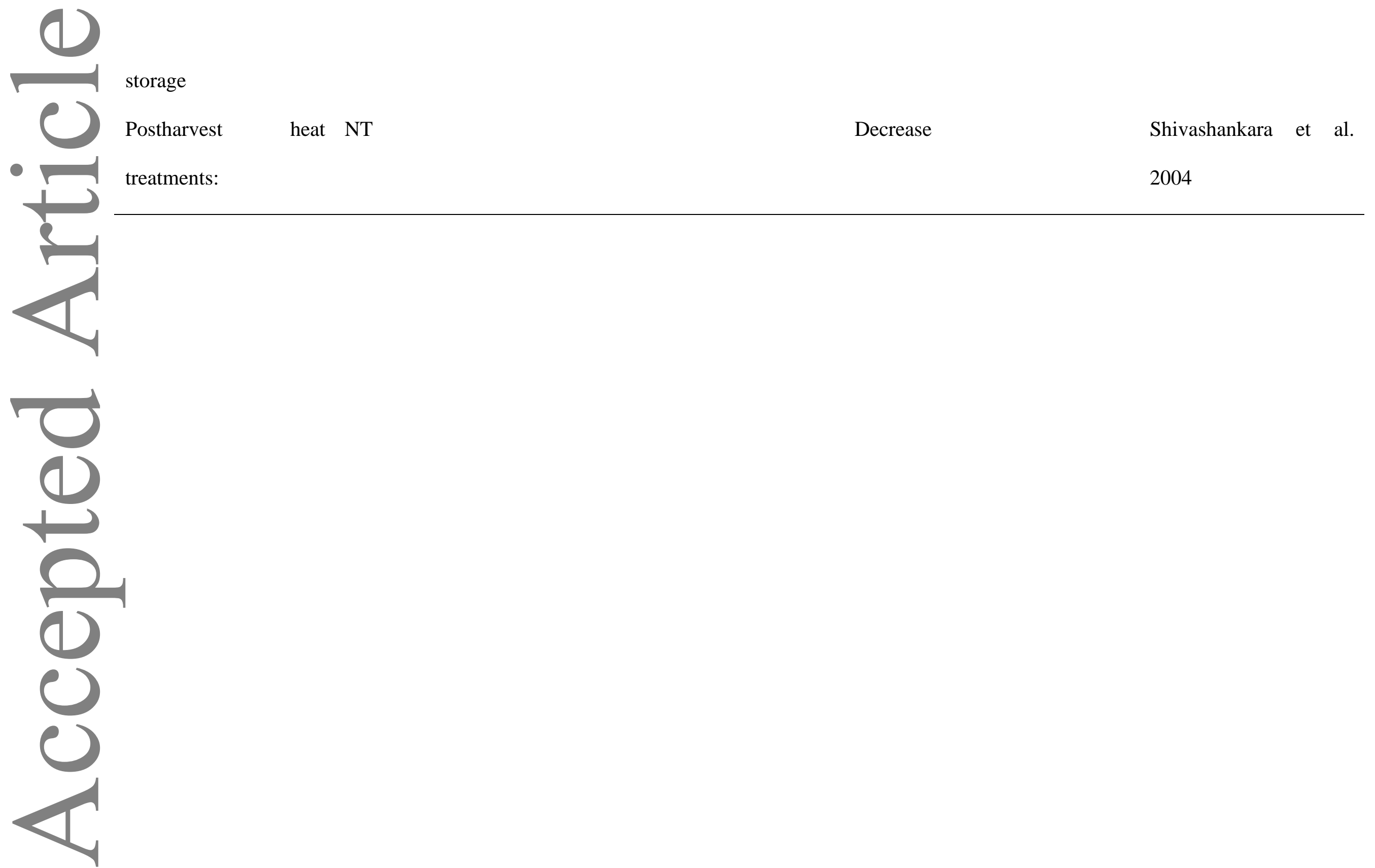

This article is protected by copyright. All rights reserved. 


\section{REGULATION OF THE CONCENTRATION OF HEALTH-PROMOTING COMPOUNDS IN MANGO FRUIT}

The rediscovery of the historic bond between plant products and human health has instigated a marked growth in the interest of botanical therapeutics, plant-based pharmaceutical products, dietary supplements and functional food among health conscious consumers worldwide. ${ }^{90}$ Many of the plant derived products with significant medicinal properties are anticipated to complement the conventional medicines in near future and thereby add a significant value to agricultural produce. ${ }^{90}$

Due to the ever increasing evidence of an inverse relationship between the regular consumption of fruit and vegetables and chronic degenerative diseases such as cardiovascular diseases and cancer, different methods to improve the content of bioactive compounds in plant products have been developed. ${ }^{85}$ Therefore; in the past few decades, several methods including simple cultural practices such as pruning and fruit thinning to complex methods such as genetic engineering and plant cell culture have been investigated and practiced with the aim of increasing the concentration of bioactive compounds in fresh horticultural products. ${ }^{85}$

Phenolic compounds and terpenoids are among the key contributors to the health benefits of different fruit including mango. Thus, a good understanding of their biosynthetic pathways and the factors that could influence their biosynthesis and degradation would be of utmost importance in developing effective and efficient methods to regulate the concentrations of desired health-promoting compounds in mango fruit. The following section will provide the mechanisms of polyphenol and terpenoid biosynthesis that occurs in mango fruit as well as in other fruit.

\section{Biosynthesis of phenolic health-promoting compounds}


Most of these phenolic compounds are classified as secondary metabolites that have a large variety of structures and functions, ${ }^{91}$ and are biosynthesized in plants during normal growth and development or when they are subjected to biotic or abiotic stresses. Biosynthesis of phenolic compounds in plants as secondary metabolites occurs via different pathways. Generally phenolic compounds are biosynthesised from the intermediates of carbohydrate metabolism via the shikimic acid pathway which is predominately found in plastids. ${ }^{92}$ The two starting compounds of shikimic acid pathway are erythrose - 4 -phosphate and phosphoenol pyruvate derived from carbohydrate metabolism during photosynthesis. ${ }^{92}$ Several phenolic secondary metabolites are then synthesized from these precursors in multiple steps ${ }^{92}$ (Fig. 6). Phenylalanine ammonia lyase (PAL) is one of the key enzymes in shikimic acid pathway which is responsible for the biosynthesis of phenolic acids. ${ }^{93}$

Derivation of erythrose - 4- phosphate (Fig. 7) and phosphoenol pyruvate (Fig. 8) from carbohydrates, production of shikimic acid (Fig. 9) and chorismic acid (Fig. 10) and the conversion of chorismate to other products can be considered as the major steps of shikimic acid pathway. ${ }^{92}$ The synthesis of phenylalanine (Fig. 11) from chorismic acid is one of the crucial steps of polyphenol biosynthesis as polyphenols are basically biosynthesised from phenylalanine. The deamination of phenylalanine by the enzyme phenylalanine ammonia-lyase (PAL) is considered as the initial step of phenolic acid biosynthesis. ${ }^{85}$ These phenolic acids, mainly cinnamic acid and its derivatives then play a key role in the synthesis of flavonoids, lignin and several other phenolic compounds. ${ }^{92}$

\section{Biosynthesis of terpenoids}

This article is protected by copyright. All rights reserved. 
Terpenoids are derived by the recurring fusion of five-carbon units called 'isoprene units'. ${ }^{94}$ Thus, they are divided in to several groups based on the number of isoprene units they possess; namely, hemiterpenes $\left(\mathrm{C}_{5}\right.$, single isoprene unit), monoterpenes $\left(\mathrm{C}_{10}\right.$, two isoprene units), sesquiterpenes $\left(\mathrm{C}_{15}\right.$, three isoprene units), diterpenes $\left(\mathrm{C}_{20}\right.$, four isoprene units), triterpenes $\left(\mathrm{C}_{25}\right.$, five isoprene units), tetraterpenes $\left(\mathrm{C}_{30}\right.$, six isoprene units) and polyterpenes (> $\mathrm{C}_{40},>8$ isoprene units). ${ }^{95}$ Plant growth regulators (cytokinins, gibberellic acid and abscisic acid), photosynthetic pigments (carotenoids and chlorophyll) are some of the most important primary terpenoid metabolites. 96 Monoterpenes, sesquiterpenes, diterpenes and triterpenes are considered as secondary metabolites. ${ }^{96}$ Monoterpenes comprise a major fraction of aroma volatile compounds in fruit such as mango, ${ }^{97}$ floral fragrances and of essential oils in plants. ${ }^{95}$ Sesquiterpenes are also found in mango fruit aroma volatile compounds ${ }^{97}$ and essential oils in plants and a number of sesquiterpenoids are found in antimicrobial compounds produced by plants as pathogen defence. ${ }^{95}$ Diterpenes include phytol, a side chain of chlorophyll molecule and several other pharmacologically important compounds such as retinol, ${ }^{95}$ whilst triterpenes include plant hormones, various membrane components, plant waxes ${ }^{95}$ and anti-carcinogenic bioactive compounds such as lupeol. ${ }^{8}$ Tetraterpenes which is the most common of all terpene groups is consisted of carotenoid pigments. ${ }^{95}$

Terpenoids could be biosynthesised via mevalonate pathway or 2-C-methyl-Derythritol-4-phophate (MEP) pathway (Fig. 12). ${ }^{94 .}{ }^{96}$ Generally, the biosynthesis of terpenoids is compartmentalized, where the mevalonate pathway is present in the cytosol and the MEP pathway in the plastids. ${ }^{95,96}$ Usually, sesquiterpenes, triterpenes and polyterpenes are syntheised in the cytosol, whilst monoterpenes, diterpenes and tetraterpenes are largely synthesised in plastids. ${ }^{95}$ 


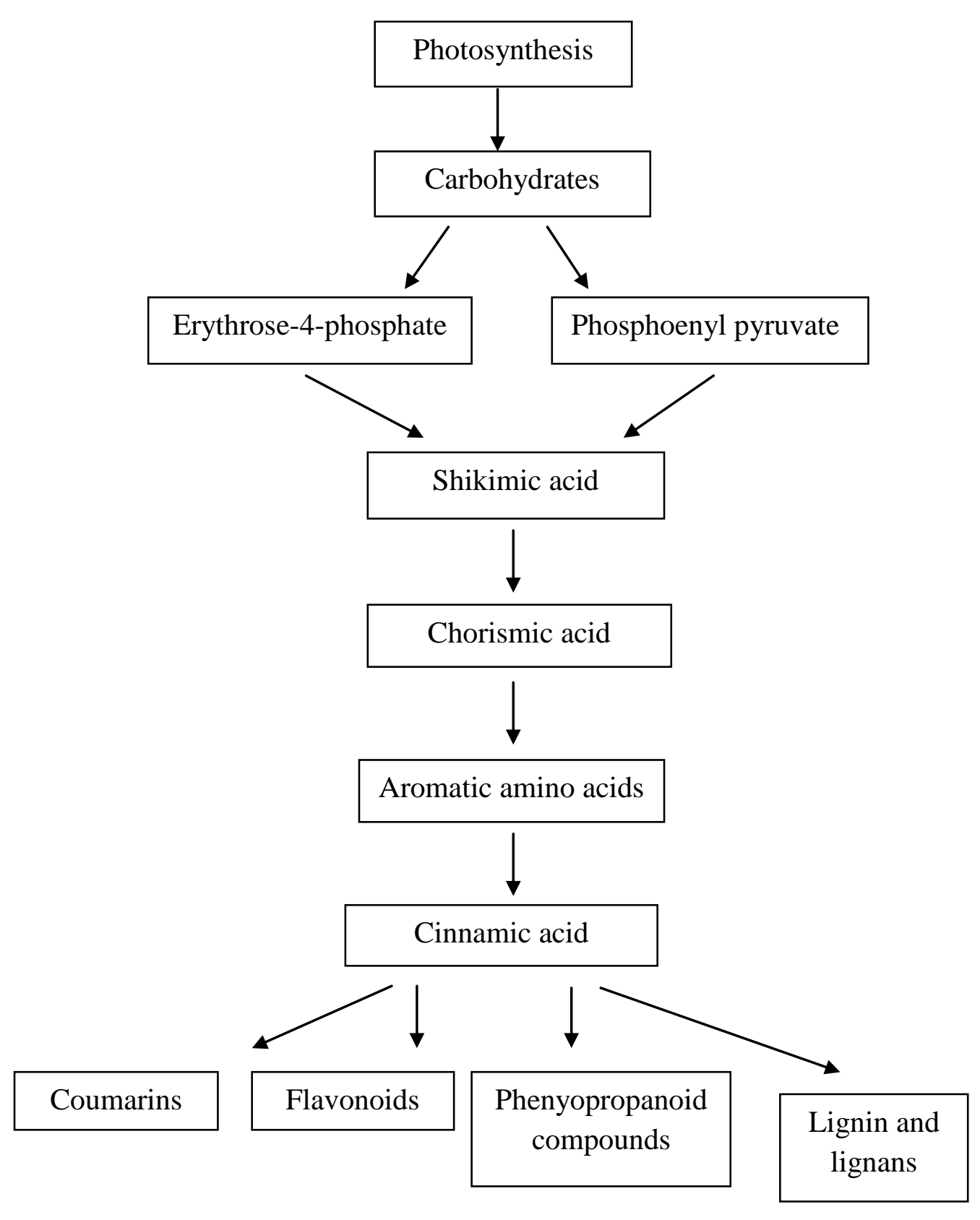

Fig. 6 Basic steps of shikimic acid pathway of phenolic biosynthesis modified from Seigler ${ }^{92}$ 
<smiles>O=C[C@H](O)[C@@H](O)COP(=O)(O)O</smiles>

Fig. 7 Erythrose-4-phosphate<smiles>C=C(OP(=O)(O)O)C(=O)O</smiles>

Fig. 8 Phosphoenol pyruvate<smiles>O=C(O)C1=C[C@@H](O)[C@H](O)[C@H](O)C1</smiles>

Fig. 9 Shikimic acid<smiles>C=C(O[C@H]1C=C(C(=O)O)C=C[C@H]1O)C(=O)O</smiles>

Fig.10 Chorismic acid<smiles>N[C@@H](Cc1ccccc1)C(=O)O</smiles>

Fig. 11 Phenylalanine

(Source: https://www.sigmaaldrich.com)

\section{Mevalonate (mevalonic acid) and MEP pathways of terpenoid biosynthesis}

Both mevalonate and MEP pathways are initiated by pyruvate (Fig. 12) which is produced during the process of photosynthesis, followed by a series of steps which ultimately synthesise different types of terpenoids. In mevalonate pathway, pyruvate is converted to acetyl- CoA, acetoacetyl CoA and 3- hydroxyl-3-methyl-glutanyl-CoA (HMG- CoA) which is then converted to mevalonic acid (Fig. 13). From mevalonic acid, isopentenyl phosphate (IPP) (Fig. 14) is derived which is subsequently converted to different types of terpenoids (Fig. 15). However, in MEP pathway, pyruvate is converted to glyceraldehydes 3-phosphate (GAP) and 1-deoxy-D-xylulose which produces 2-C-methyl-D-erythritol-4-phosphate (Fig.15), which is later converted to IPP. Then the major sub groups of terpenoids are synthesised from IPP. ${ }^{95}$ 


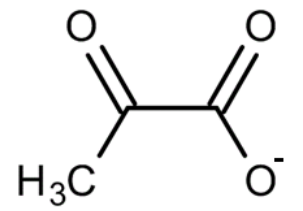

Fig. 12 Pyruvate

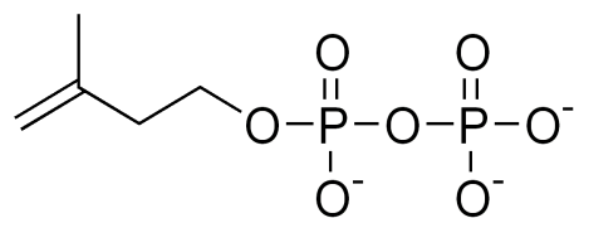

Fig. 14 Isopentenyl phosphate (IPP)<smiles>C[C@](O)(CCO)CC(=O)O</smiles>

Fig. 13 Mevalonic acid<smiles>C[C@@](O)(CO)[C@H](O)COP(=O)(O)O</smiles>

Fig. 15 2-C-Methyl-D-erythritol-4-

Phosphate

(Source: https://www.sigmaaldrich.com) 


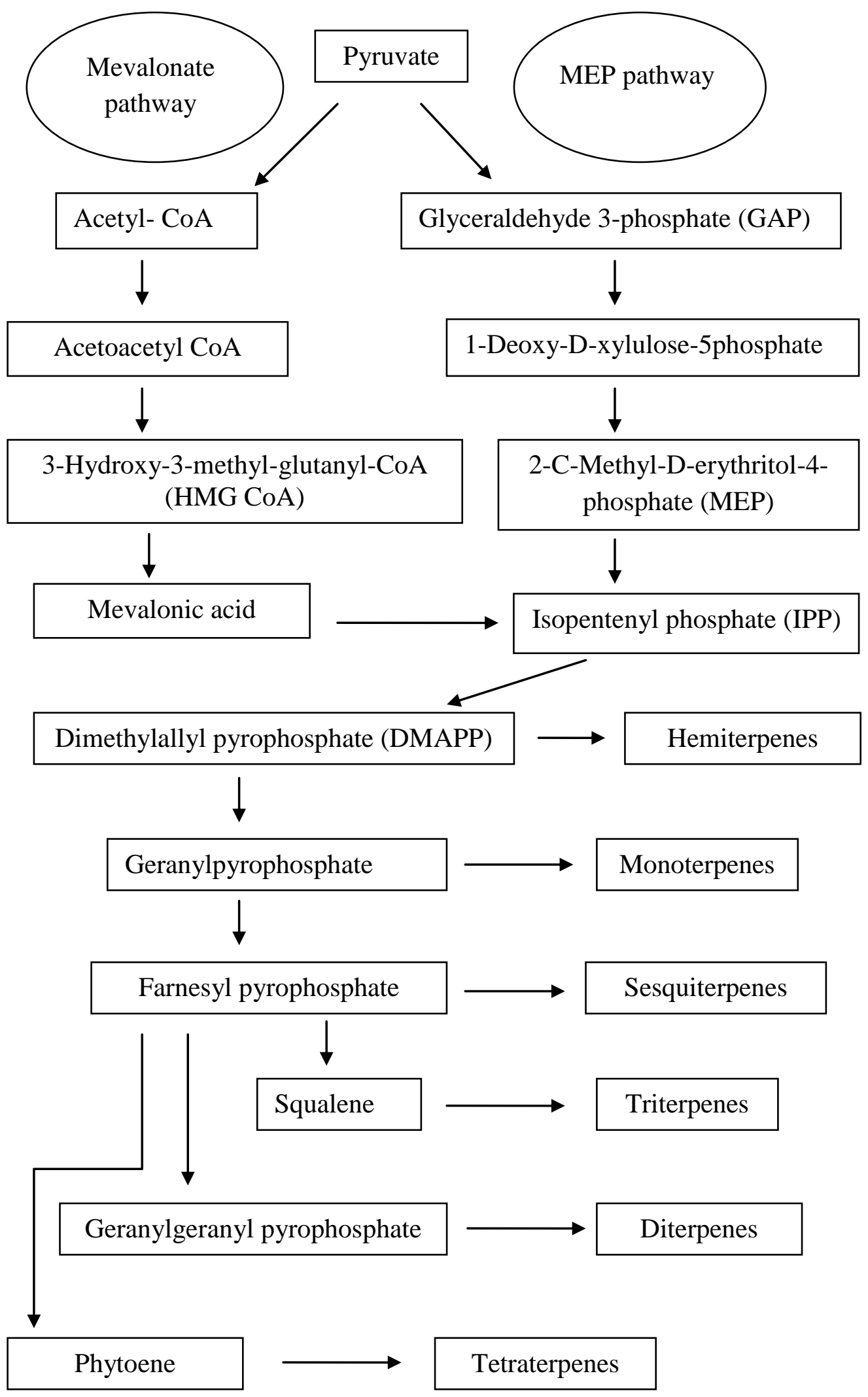

Fig. 16 Major steps of Mevalonate and MEP pathways of terpenoid biosynthesis modified from Croteau et al ${ }^{95}$

This article is protected by copyright. All rights reserved. 


\section{TOOLS TO INCREASE THE CONCENTRATION OF HEALTH- PROMOTING COMPOUNDS IN MANGO FRUIT}

Due to the increasing awareness of the health benefits of secondary compounds produced in plants, the concern of consumers has been shifted from the external quality of fruit and vegetables to their concentration of health-promoting compounds. ${ }^{83}$ Thus, a need of new technologies or strategies to add value to fruit and vegetables by increasing their concentration of desired health-promoting compounds has been created. ${ }^{84}$ In addition to their health prospects, these value added commodities would improve trade prospects of growers and food industry in growing health-oriented markets.

\section{Plant cell culture}

Plant cell culture is another potential alternative for the production of desired secondary metabolites that are generally difficult to synthesise chemically or extract directly from plants. ${ }^{98,99}$ However, low yield of compounds obtained via this method is one of the key constraints. ${ }^{85}$ The productivity of many compounds is still not competitive enough for commercial applications. ${ }^{99}$

\section{Elicitors}

Application of physical and chemical elicitors is becoming the most promising alternative to overcome the constraints faced by genetic engineering and plant cell culture. ${ }^{85}$ Low temperature, ultraviolet and gamma irradiation and altered gas composition are among the physical elicitor's treatments, whilst plant signalling 
molecules such as methyl jasmonate (MeJA), salicylic acid (SA) and ethylene are considered as the chemical elicitors. ${ }^{83}$ Plant defence against biotic or abiotic stress conditions involves triggered synthesis of low molecular weight compounds called phytoalexins. ${ }^{100}$ Thus, a chemical elicitor can be considered as a compound that can stimulate phytoalexin accumulation in plants. ${ }^{99}$

Since plant secondary metabolites are generally synthesised to protect plants from various biotic and abiotic stresses including pest and disease attacks, moisture stress and extreme temperatures; stress induction could be used to stimulate the production of such plant secondary metabolites. ${ }^{99}$ There is growing evidence on the ability of plants to biosynthesize higher concentrations of secondary metabolites as a response to induced abiotic stresses. ${ }^{101}$ Organically grown fruit are believed to contain more secondary metabolites as such situations induce plants and fruit to use their own natural defence mechanisms against biotic and abiotic stress. ${ }^{76}$ Hence, targeted postharvest elicitor treatments could be used as a promising tool to produce fruit and vegetables with higher concentrations of phytochemicals to cater the growing consumer demand. ${ }^{83}$ This technique is considered as a promising practical, effective and safe tool when compared with genetic engineering and plant cell culture. ${ }^{84,85}$ However, the influence of elicitor treatments on the levels of terpenoids and phenolic health-promoting compounds in mango fruit is rather limited. Even though a number of studies have reported the pre- and postharvest effects of the application of MeJA, SA and NO on chilling injury, physico-chemical and health beneficial properties in different mango cultivars including 'Tommy Atkins' (Gonzalez-Aguilar et al. 2000), 102 'Kent' (Gonzalez-Aguilar et al. 2001), ${ }^{103}$ Kensington Pride' (Lalel et al 2003 104; Joyce et al $2001^{105}$, Zaharah and Singh, $2011^{106}$ ) , 'Matisu' (Zeng et al., $2006^{107}$ ) 
and 'Chausa' (Barman et al, 2014), ${ }^{108}$ their effect on the concentrations of lupeol, mangiferin or phenolic acids are seldom discussed.

A study carried out to investigate the effect of postharvest application of chemical elicitors MeJA, SA and NO on the concentrations of these compounds in the pulp and peel of ripe 'Kensington Pride' mango fruit revealed that, the levels of mangiferin, gallic acid, chlorogenic acid and total phenols in both pulp and peel as well as lupeol and caffeic acid in the peel were significantly higher with MeJA $\left(10^{-5}\right.$ or $10^{-4} \mathrm{M}$ ) fumigation compared to untreated control. Similarly, the concentrations of mangiferin and ferulic acid in the pulp and peel were significantly higher with 1 and 2 mmol L ${ }^{-1} \mathrm{SA}$ dip, lupeol in the pulp with 2 and $3 \mathrm{mmol} \mathrm{L}^{-1} \mathrm{SA}$ dip, chlorogenic acid in both pulp and peel with $2 \mathrm{mmol} \mathrm{L}^{-1} \mathrm{SA}$ dip and vanillic acid in the pulp with all SA treatments $\left(1,2\right.$ and $\left.3 \mathrm{mmol} \mathrm{L}^{-1}\right)$ compared to control. The concentrations of lupeol, mangiferin, gallic and chlorogenic acids in both the pulp and peel, vanillic, ferulic and caffeic acids and total phenols in the ripe pulp were significantly higher with NO (20 and/or $40 \mu \mathrm{L} \mathrm{L}^{-1}$ ) fumigation compared to the control. ${ }^{109}$ On the whole, fumigation with $10^{-5} \mathrm{M}$ and/or $10^{-4} \mathrm{M}$ MeJA for $24 \mathrm{~h}$ and fumigation with 20 and/or $40 \mu \mathrm{L} \mathrm{L}^{-1} \mathrm{NO}$ for $2 \mathrm{~h}$ could be considered as feasible methods to increase the concentrations of mangiferin, gallic and chlorogenic acids in pulp and peel of ripe mango fruit to cater for the health-oriented markets and commercial industries.

\section{Stimulation of terpenoid biosynthesis}

The stimulation of terpenoid biosynthesis would possibly increase the concentrations of health-promoting compounds such as carotenoids and lupeol in mango fruit. The conversion of acetyl-CoA to acetoacetyl-CoA and 3-hydroxy-3-methylglutaryl-CoA (HMG- CoA) are considered as the first two steps in terpenoid biosynthesis via 
mevalonic acid pathway as mentioned earlier (Fig. 16). ${ }^{93}$ The enzymes that catalyse these two reactions: Acetyl-CoA acetyltransferase and HMG-CoA synthase utilize bivalent metal ion $\mathrm{Fe}^{2+}$ as a cofactor. ${ }^{93}$ Subsequently, isopentenyl pyrophosphate (IPP), geranyl pyrophosphate (GPP) and farnesyl pyrophospahate (FPP) which involve in the production of hemiterpenes, monoterpenes, sesquiterpenes, diterpenes and tetraterpenes are biosynthesized. $\mathrm{Mg}^{2+}$ or $\mathrm{Mn}^{2+}$ is utilized as cofactors by the enzymes involved in the biosynthesis of these compounds: Pyrophosphomevalonate decarboxylase, IPP isomerise, GPP synthase and FPP synthase (Fig. 17). 93, 110

The influence of a pre-harvest spray application of $\mathrm{FeSO}_{4}\left(\mathrm{Fe}^{2+}\right), \mathrm{MgSO}_{4}\left(\mathrm{Mg}^{2+}\right)$ and $\mathrm{MnSO}_{4}\left(\mathrm{Mn}^{2+}\right)(0.2 \%$ and $0.3 \%) 30 \mathrm{~d}$ before harvest date on the levels of terpenoids and phenolic compounds in the pulp and peel of ripe 'Kensington Pride' mango fruit showed that the concentration of lupeol was significantly higher in the peel of fruit applied with all six treatments, whilst it was the highest in the pulp of fruit treated with $0.3 \% \mathrm{FeSO}_{4}$. The level of mangiferin in the pulp was significantly higher in the fruit treated with $0.2 \% \mathrm{FeSO}_{4}, \mathrm{MgSO}_{4}$ and $\mathrm{MnSO}_{4}$ whilst the concentrations of gallic, ferulic and caffeic acids in the peel and chlorogenic acid in both the pulp and peel were highest in fruit sprayed with $0.2 \% \mathrm{FeSO}_{4} \cdot{ }^{111}$ Overall, spray application of $0.2 \%$ aqueous $\mathrm{FeSO}_{4} 30 \mathrm{~d}$ before harvest was identified as a viable commercial approach to obtain value added mango fruit with higher levels of lupeol, mangiferin, gallic, ferulic and caffeic acids in the peel and chlorogenic acid in the pulp. ${ }^{111}$

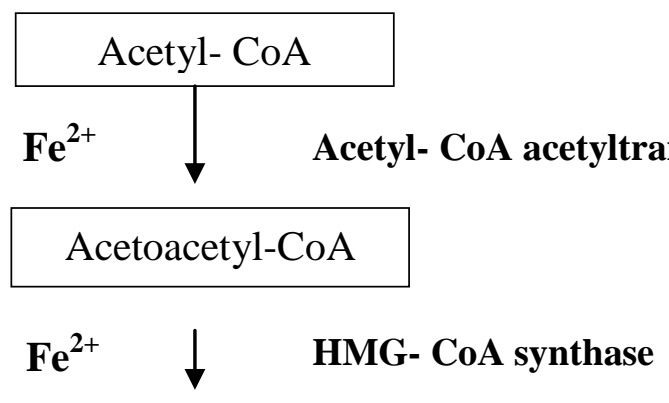

This article is protected by copyright. All rights reserved. 
future the influence of pre-harvest elicitation methods such as regulated and deficit irrigation and simple agronomic practices such as reflective mulches on the concentrations of bioactive compounds in mango fruit could be investigated. Moreover, the dynamics in the activity of phenylalanine ammonia lyase (PAL) and other key enzymes involved in terpenoid and polyphenol biosynthetic pathways under different pre- and postharvest treatments and conditions could be investigated for better manipulation of these processes in future studies. The influence of pre- and postharvest elicitation on the expression of gene(s) involved in terpenoid and polyphenol biosynthesis could be investigated to understand the mechanism of action of these elicitors in enhancing the levels of different health promoting compounds in mango fruit. Furthermore, elevated levels of health-promoting compounds present in the pulp and peel could be added as an objective in future mango breeding programmes, whilst identification of germplasm with higher levels of these compounds could be used in hybridization.

\section{CONCLUSION}

Mango fruit is a rich source of many health-beneficial phytochemicals such as lupeol, mangiferin and different phenolic acids. However, there still is much scope for further increasing the levels of these compounds through various pre- and postharvest manipulations., delaying harvesting of mango fruit until sprung stage, exposing hard green mature mangoes to chilling temperatures $\left(5{ }^{\circ} \mathrm{C}\right)$ for $12 \mathrm{~d}$ prior to ripening, elicitation of polyphenol and terpenoid biosynthesis by fumigation of mature green mango fruit with $10^{-5} \mathrm{M}$ and/or $10^{-4} \mathrm{M}$ MeJA for $24 \mathrm{~h}$ or fumigation with 20 and/or 40 $\mu \mathrm{L} \mathrm{L}^{-1} \mathrm{NO}$ for $2 \mathrm{~h}$ and spray application of $0.2 \%$ aqueous $\mathrm{FeSO}_{4} 30 \mathrm{~d}$ before harvest for the exogenous supply of enzyme cofactor $\mathrm{Fe}^{2+}$ can be considered as viable methods 
to obtain ripe mango fruit with higher levels of lupeol, mangiferin and phenolic acids in both pulp and peel. These phytochemical rich fruit can play a beneficial role in diet to reduce the risk of chronic degenerative diseases. Moreover, the value added peel would provide a good source to extract these compounds for food processing and nutraceutical industries.

\section{ACKNOWLEDGEMENT}

M.D.K Vithana gratefully acknowledges the Endeavour Postgraduate Award (PhD) offered by the Australian government and Wayamba University, Sri Lanka for granting study leave for her $\mathrm{PhD}$.

\section{REFERENCES}

1. Masibo M, He Q. Mango bioactive compounds and related nutraceutical properties—a review. Food Rev Int 25(4):346-70 (2009).

2. Masibo M, He Q. Major mango polyphenols and their potential significance to human health. Compr Rev Food Sci Food Saf 7(4): 309-319 (2008).

3. Jahurul MH, Zaidul IS, Ghafoor K, Al-Juhaimi FY, Nyam KL, Norulaini NA, Sahena F, Omar AM. Mango (Mangifera indica L.) by-products and their valuable components: A review. Food Chem. 183:173-80 (2015).

4. Ajila CM, Naidu KA, Bhat SG, Rao UP. Bioactive compounds and antioxidant potential of mango peel extract. Food Chem 105(3): 982-988(2007).

This article is protected by copyright. All rights reserved. 
5. Berardini N, Knödler M, Schieber A, Carle R. Utilization of mango peels as a source of pectin and polyphenolics. Innov Food Sci \& Emerg Technol 6(4): $442-452(2005)$.

6. Kim H, Moon JY, Kim H, Lee DS, Cho M, Choi, HK, Kim S, Mossadik A, Cho SK. Antioxidant and anti-proliferative activities of mango (Mangifera indica L.) flesh and peel. Food Chem 121(2): 429-436 (2010).

7. Palafox-Carlos H, Yahia EM, González-Aguilar GA. Identification and quantification of major phenolic compounds from mango (Mangifera indica, cv. Ataulfo) fruit by HPLC-DAD-MS/MS-ESI and their individual contribution to the antioxidant activity during ripening. Food Chem 135(1): 105-111 (2012a).

8. Saleem M. Lupeol, a novel anti-inflammatory and anti-cancer dietary triterpene. Cancer Lett 285(2), 109-115 (2009).

9. Vithana MD, Singh Z, Johnson SK. Dynamics in the concentrations of healthpromoting compounds: lupeol, mangiferin and different phenolic acids during postharvest ripening of mango fruit. J Sci Food and Agric. 98 (4): 1460-1468 (2018a).

10. Ruiz-Montañez G, Ragazzo-Sánchez JA, Calderón-Santoyo M, Velazquez-De La Cruz G, de León JR, Navarro-Ocaña A. Evaluation of extraction methods 
for preparative scale obtention of mangiferin and lupeol from mango peels (Mangifera indica L.). Food Chem 159: 267-272 (2014).

11. Srivastava P, Killadi B, Shanker K. Uni-dimensional double development HPTLC-densitometry method for simultaneous analysis of mangiferin and lupeol content in mango (Mangifera indica) pulp and peel during storage. Food Chem 176: 91-98 (2015).

12. Gallo MB, Sarachine MJ. Biological activity of lupeol. Int J Biomed Pharm Sci, 1: 46-66 (2009).

13. Syed DN, Mukhtar H. Botanicals for the prevention and treatment of cutaneous melanoma. Pigment Cell \& Melanoma Res 24(4): 688-702 (2011).

14. Prasad S, Nigam N, Kalra N, Shukla Y. Regulation of signalling pathways involved in lupeol induced inhibition of proliferation and induction of apoptosis in human prostate cancer cells. Mol Carcinog 47: 916-924 (2008).

15. Tarapore RS, Siddiqui IA, Adhami VM, Spiegelman VS, Mukhtar H. The dietary terpene lupeol targets colorectal cancer cells with constitutively active Wnt/ß-catenin signaling. Mol Nutr Food Res 57(11):1950-8 (2013).

16. Sturm S, Gil RR, Chai HB, Ngassapa OD, Santisuk T, Reutrakul V, Howe A, Moss M, Besterman JM, Yang SL, Farthing JE. Lupane derivatives from 
Lophopetalum wallichii with farnesyl protein transferase inhibitory activity. $J$ nat prod 59(7):658-663 (1996).

17. Moriarty DM, Huang J, Yancey CA, Zhang P, Setzer WN, Lawton RO, Bates $\mathrm{RB}$, Caldera S. Lupeol is the cytotoxic principle in the leaf extract of Dendropanax cf. querceti. Planta med 64(04):370-2. (1998).

18. Wada SI, Iida A, Tanaka R. Screening of Triterpenoids Isolated from Phyllanthus flexuosus for DNA Topoisomerase Inhibitory Activity. J nat prod 64(12):1545-1547. (2001).

19. Chaturvedula VP, Zhou BN, Gao Z, Thomas SJ, Hecht SM, Kingston DG. New lupane triterpenoids from Solidago canadensis that inhibit the lyase activity of DNA polymerase $\beta$. Bioorg med chem 12(23):6271-6275 (2004).

20. Aratanechemuge Y, Hibasami H, Sanpin K, Katsuzaki H, Imai K, Komiya T. Induction of apoptosis by lupeol isolated from mokumen (Gossampinus malabarica L. Merr) in human promyelotic leukemia HL-60 cells. Oncol rep 11(2):289-292 (2004).

21. Saleem M, Kweon MH, Yun JM, Adhami VM, Khan N, Syed DN, Mukhtar H. A novel dietary triterpene Lupeol induces fas-mediated apoptotic death of androgen-sensitive prostate cancer cells and inhibits tumor growth in a xenograft model. Cancer Res 65(23):11203-11213 (2005).

This article is protected by copyright. All rights reserved. 
22. Saleem M, Kaur S, Kweon MH, Adhami VM, Afaq F, Mukhtar H. Lupeol, a fruit and vegetable based triterpene, induces apoptotic death of human pancreatic adenocarcinoma cells via inhibition of Ras signalling pathway. Carcinogenesis 26(11):1956-1964 (2005).

23. Saleem M, Maddodi N, Zaid MA, Khan N, bin Hafeez B, Asim M, Suh Y, Yun JM, Setaluri V, Mukhtar H. Lupeol inhibits growth of highly aggressive human metastatic melanoma cells in vitro and in vivo by inducing apoptosis. Clin Cancer Res 14(7):2119-2127 (2008).

24. Prasad S, Madan E, Nigam N, Roy P, George J, Shukla Y. Induction of apoptosis by lupeol in human epidermoid carcinoma A431 cells through regulation of mitochondrial, Akt/PKB and NF-kappaB signaling pathways. Cancer biol ther 8(17):1632-1639 (2009).

25. Zhang L, Zhang Y, Zhang L, Yang X, Lv Z. Lupeol, a dietary triterpene, inhibited growth, and induced apoptosis through down-regulation of DR3 in SMMC7721 cells. Cancer investig 27(2):163-170 (2009).

26. Andrikopoulos NK, Kaliora AC, Assimopoulou AN, Papapeorgiou VP. Biological activity of some naturally occurring resins, gums and pigments against in vitro LDL oxidation. Phytother res. 17(5):501-507 (2003).

This article is protected by copyright. All rights reserved. 
27. Saleem R, Ahmad SI, Ahmed M, Faizi Z, Zikr-ur-Rehman S, Ali M, Faizi S. Hypotensive activity and toxicology of constituents from Bombax ceiba stem bark. Biol pharm bull 26(1):41-46 (2003).

28. Sudharsan PT, Mythili Y, Selvakumar E, Varalakshmi P. Cardioprotective effect of pentacyclic triterpene, lupeol and its ester on cyclophosphamideinduced oxidative stress. Hum exp toxicol 24(6):313-318 (2005).

29. Fernández A, Álvarez A, García MD, Sáenz MT. Anti-inflammatory effect of Pimenta racemosa var. ozua and isolation of the triterpene lupeol. Farmaco. 56(4):335-338 (2001).

30. Bani S, Kaul A, Khan B, Ahmad SF, Suri KA, Gupta BD, Satti NK, Qazi GN. Suppression of $\mathrm{T}$ lymphocyte activity by lupeol isolated from Crataeva religiosa. Phytother res 20(4):279-287 (2006).

31. Vasconcelos JF, Teixeira MM, Barbosa-Filho JM, Lúcio AS, Almeida JR, De Queiroz LP, Ribeiro-dos-Santos R, Soares MB. The triterpenoid lupeol attenuates allergic airway inflammation in a murine model. Int immunopharmacol 8(9): 1216-1221 (2008).

32. Ding Y, Nguyen HT, Kim SI, Kim HW, Kim YH. The regulation of inflammatory cytokine secretion in macrophage cell line by the chemical constituents of Rhus sylvestris. Bioorg medi chem lett 19(13):3607-3610 (2009).

This article is protected by copyright. All rights reserved. 
33. Siddique HR, Saleem M. Beneficial health effects of lupeol triterpene: a review of preclinical studies. Life Sci 88(7): 285-293 (2011).

34. Martínez G, Giuliani A, Leon OS, Perez G, Núñez Selles AJ. Effect of Mangifera indica L. extract (QF808) on protein and hepatic microsome peroxidation. Phytotherapy Res 15(7): 581-585 (2001).

35. Puccio H, Kœnig M. Friedreich ataxia: a paradigm for mitochondrial diseases. Curr Opin Genetics Dev 12(3): 272-277 (2002).

36. Halliwell B, Gutteridge JM. Oxygen free radicals and iron in relation to biology and medicine: some problems and concepts. Arch Biochem Biophys 246(2): 501-514 (1986).

37. Halliwell B. Oxidative stress and neurodegeneration: where are we now? $J$ Neurochem 97(6): 1634-1658 (2006).

38. Pawlak W, Kedziora J, Zolynski K, Kedziora-Kornatowska K, Blaszczyk J, Witkowski P, Zieleniewski J. Effect of long term bed rest in men on enzymatic antioxidative defence and lipid peroxidation in erythrocytes. J Gravit Physiol 5(1): P163-4 (1998).

39. Rodríguez J, Di Pierro D, Gioia M, Monaco S, Delgado R, Coletta M, Marini S. Effects of a natural extract from Mangifera indica L, and its active 
compound, mangiferin, on energy state and lipid peroxidation of red blood cells. Biochim Biophys Acta 1760(9): 1333-1342 (2006).

40. Muruganandan S, Srinivasan K, Gupta S, Gupta PK, Lal J. Effect of mangiferin on hyperglycemia and atherogenicity in streptozotocin diabetic rats. J Ethnopharm 97(3): 497-501 (2005).

41. Yoshikawa M, Nishida N, Shimoda H, Takada M, Kawahara Y, Matsuda H. Polyphenol constituents from Salacia species: quantitative analysis of mangiferin with alpha-glucosidase and aldose reductase inhibitory activities. Yakugaku Zasshi: J Pharmac Soc Japan 121(5): 371-378 (2001).

42. Aderibigbe AO, Emudianughe TS, Lawal BA. Evaluation of the antidiabetic action of Mangifera indica in mice. Phytotherapy Research, 15(5): 456-458 (2001).

43. Yoshimi N, Matsunaga K, Katayama M, Yamada Y, Kuno T, Qiao Z, Mori H. The inhibitory effects of mangiferin, a naturally occurring glucosylxanthone, in bowel carcinogenesis of male F344 rats. Cancer Lett 163(2): 163-170 (2001).

44. Khoddami A, Wilkes MA, Roberts TH. Techniques for analysis of plant phenolic compounds. Molecules 18(2), 2328-2375 (2013).

45. Kim Y, Brecht JK, Talcott ST. Antioxidant phytochemical and fruit quality changes in mango (Mangifera indica L.) following hot water immersion and controlled atmosphere storage. Food Chem 105(4): 1327-1334 (2007).

This article is protected by copyright. All rights reserved. 
46. Yen GC, Duh PD, Tsai HL. Antioxidant and pro-oxidant properties of ascorbic acid and gallic acid. Food Chem 79(3): 307-313 (2002).

47. Madsen HL, Bertelsen G. Spices as antioxidants. Trends Food Sci Technol 6(8): 271-277 (1995).

48. Verma S, Singh A, Mishra A. Gallic acid: molecular rival of cancer. Environ Toxicol Pharmacol 35(3): 473-485 (2013).

49. Ho HH, Chang CS, Ho WC, Liao SY, Lin WL, Wang CJ. Gallic acid inhibits gastric cancer cells metastasis and invasive growth via increased expression of RhoB, downregulation of AKT/small GTPase signals and inhibition of NF- $\mathrm{B}$ activity. Toxicol Appl Pharmacol 266(1): 76-85 (2013).

50. Chen HM, Wu YC, Chia YC., Chang FR, Hsu HK, Hsieh YC, Yuan SS. Gallic acid, a major component of Toona sinensis leaf extracts, contains a ROSmediated anti-cancer activity in human prostate cancer cells. Cancer Lett, 286(2): 161-171 (2009).

51. Reddy TC, Reddy DB, Aparna A, Arunasree KM, Gupta G, Achari C, Reddanna P. Anti-leukemic effects of gallic acid on human leukemia K562 cells: downregulation of $\mathrm{COX}-2$, inhibition of BCR/ABL kinase and NF- $\kappa \mathrm{B}$ inactivation. Toxicol in Vitro, 26(3): 396-405 (2012).

This article is protected by copyright. All rights reserved. 
52. Liao CL, Lai KC, Huang AC, Yang JS, Lin JJ, Wu SH, Chung JG. Gallic acid inhibits migration and invasion in human osteosarcoma U-2 OS cells through suppressing the matrix metalloproteinase-2/-9, protein kinase $\mathrm{B}(\mathrm{PKB})$ and PKC signalling pathways. Food Chem Toxicol 50(5), 1734-1740 (2012).

53. Parihar S, Gupta A, Chaturvedi AK, Agarwal J, Luqman S, Changkija B, Dwivedi A. Gallic acid based steroidal phenstatin analogues for selective targeting of breast cancer cells through inhibiting tubulin polymerization. Steroids 77(8): 878-886 (2012).

54. Ji BC, Hsu WH, Yang JS, Hsia TC, Lu CC, Chiang JH, Gibson Wood W. Gallic acid induces apoptosis via caspase-3 and mitochondrion-dependent pathways in vitro and suppresses lung xenograft tumor growth in vivo. J Agri Food Chem 57(16): 7596-7604 (2009).

55. Veluri R, Singh RP, Liu Z, Thompson JA, Agarwal R, Agarwal C. Fractionation of grape seed extract and identification of gallic acid as one of the major active constituents causing growth inhibition and apoptotic death of DU145 human prostate carcinoma cells. Carcinogenesis 27(7): 1445-1453 (2006).

56. Inoue M, Suzuki R, Sakaguchi N, Li Z, Takeda T, Ogihara Y, Jiang BY, Chen Y. Selective induction of cell death in cancer cells by gallic acid. Biol Pharm Bull 18(11): 1526-1530 (1995).

This article is protected by copyright. All rights reserved. 
57. Farah A, Monteiro M, Donangelo CM, Lafay S. Chlorogenic acids from green coffee extract are highly bioavailable in humans. $J$ Nutr 138(12): 2309-2315 (2008).

58. Li S, Bian H, Liu Z, Wang Y, Dai J, He W, Luo J. Chlorogenic acid protects MSCs against oxidative stress by altering FOXO family genes and activating intrinsic pathway. Eur J Pharmacol 674(2), 65-72 (2012).

59. Cho AS, Jeon SM, Kim MJ, Yeo J, Seo KI, Choi MS, Lee MK. Chlorogenic acid exhibits anti-obesity property and improves lipid metabolism in high-fat diet-induced-obese mice. Food Chem Toxicol 48(3): 937-943 (2010).

60. Kim HR, Lee DM, Lee SH, Seong AR, Gin DW, Hwang JA, Park JH. Chlorogenic acid suppresses pulmonary eosinophilia, IgE production, and Th2type cytokine production in an ovalbumin-induced allergic asthma: activation of STAT-6 and JNK is inhibited by chlorogenic acid. Int J Immunopharmacol 10(10): 1242-1248 (2010).

61. Zhang X, Huang H, Yang T, Ye Y, Shan J, Yin Z, Luo, L. Chlorogenic acid protects mice against lipopolysaccharide-induced acute lung injury. Injury 41(7): 746-752 (2010).

62. Shi H, Dong L, Jiang J, Zhao J, Zhao G, Dang X, Lu X, Jia M. Chlorogenic acid reduces liver inflammation and fibrosis through inhibition of toll-like receptor 4 signalling pathway. Toxicology 303: 107-114 (2013).

This article is protected by copyright. All rights reserved. 
63. Ong KW, Hsu A, Tan BK. Anti-diabetic and anti-lipidemic effects of chlorogenic acid are mediated by ampk activation. Biochem Pharmacol 85(9): 1341-1351 (2013).

64. Yun N, Kang JW, Lee SM. Protective effects of chlorogenic acid against ischemia/reperfusion injury in rat liver: molecular evidence of its antioxidant and anti-inflammatory properties. J Nutr Biochem 23(10): 1249-1255 (2012).

65. Zheng W, Wang SY. Antioxidant activity and phenolic compounds in selected herbs. J Agric Food Chem 49(11): 5165-5170 (2001).

66. Kumar S, Prahalathan P, Raja B. Vanillic acid: a potential inhibitor of cardiac and aortic wall remodeling in l-NAME induced hypertension through upregulation of endothelial nitric oxide synthase. Environ Toxicol Pharmacol 38(2): 643-652 (2014).

67. Prince PS, Rajakumar S, Dhanasekar K. Protective effects of vanillic acid on electrocardiogram, lipid peroxidation, antioxidants, proinflammatory markers and histopathology in isoproterenol induced cardiotoxic rats. Eur J Pharmacol 668(1): 233-240 (2011).

68. Sindhu G, Nishanthi E, Sharmila R. Nephroprotective effect of vanillic acid against cisplatin induced nephrotoxicity in wistar rats: a biochemical and molecular study. Environ Toxicol Pharmacol 39(1): 392-404 (2015).

69. Ou S, Kwok KC. Ferulic acid: pharmaceutical functions, preparation and applications in foods. J Sci Food Agric 84(11): 1261-1269 (2004).

This article is protected by copyright. All rights reserved. 
70. Kanski J, Aksenova M, Stoyanova A, Butterfield DA. Ferulic acid antioxidant protection against hydroxyl and peroxyl radical oxidation in synaptosomal and neuronal cell culture systems in vitro: structure-activity studies. $J$ Nutr Biochem 13(5): 273-281 (2002).

71. Gülçin İ. Antioxidant activity of caffeic acid (3, 4-dihydroxycinnamic acid). Toxicology 217(2): 213-220 (2006).

72. Jung UJ, Lee MK, Park YB, Jeon SM, Choi MS. Antihyperglycemic and antioxidant properties of caffeic acid in $\mathrm{db} / \mathrm{db}$ mice. $J$ Pharmacol Exp Ther 318(2): 476-483 (2006).

73. Sevgi K, Tepe B, Sarikurkcu C. Antioxidant and DNA damage protection potentials of selected phenolic acids. Food Chem Toxicol 77, 12-21 (2015).

74. Iyer CPA, Schnell RJ. Breeding and genetics. In Litz, R. E. (Ed. 2), The mango: botany, production and uses, CAB International, Wallingford, UK. 1941 (2009).

75. Stafford AE. Mango. In Handbook of Tropical Fruits; Chan HT. (Ed). Marcel Dekker: New York, Basel. 399-431 (1983).

This article is protected by copyright. All rights reserved. 
76. Ribeiro SM, Barbosa LC, Queiroz JH, Knödler M, Schieber A. Phenolic compounds and antioxidant capacity of Brazilian mango (Mangifera indica L.) varieties. Food Chem 110(3): 620-626 (2008).

77. Berardini N, Fezer R, Conrad J, Beifuss U, Carle R, Schieber A. Screening of mango (Mangifera indica L.) cultivars for their contents of flavonol $\mathrm{O}$-and xanthone C-glycosides, anthocyanins, and pectin. J Agric Food Chem 53(5), 1563-1570 (2005).

78. Manthey JA, Perkins-Veazie P. Influences of harvest date and location on the levels of $\beta$-carotene, ascorbic acid, total phenols, the in vitro antioxidant capacity, and phenolic profiles of five commercial varieties of mango (Mangifera indica L.). J Agric Food Chem 57(22): 10825-10830 (2009).

79. Ma X, Wu H, Liu L, Yao Q, Wang S, Zhan R, Xing S, Zhou Y. Polyphenolic compounds and antioxidant properties in mango fruits. Sci Hort 129(1): 102107 (2011).

80. Li L, Wang S, Chen J, Xie J, Wu H, Zhan R, Li W. Major antioxidants and in vitro antioxidant capacity of eleven mango (Mangifera indica L.) cultivars. Int J Food Prop 17(8): 1872-1887 (2014).

81. Palafox-Carlos H, Yahia E, Islas-Osuna MA, Gutierrez-Martinez P, RoblesSánchez M, González-Aguilar GA. Effect of ripeness stage of mango fruit 
(Mangifera indica L., cv. Ataulfo) on physiological parameters and antioxidant activity. Sci Hort 135, 7-13 (2012b).

82. Vithana MD, Singh Z, Johnson SK. Harvest maturity stage affects the concentrations of health-promoting compounds: Lupeol, mangiferin and phenolic acids in the pulp and peel of ripe 'Kensington Pride' mango fruit. Sci Hort. 243 (3): 125-130, (2019)

83. Schreiner M, Huyskens-Keil S. Phytochemicals in fruit and vegetables: health promotion and postharvest elicitors. Crit Rev Plant Sci 25(3): 267-278 (2006).

84. Cisneros-Zevallos L. The use of controlled postharvest abiotic stresses as a tool for enhancing the nutraceutical content and adding-value of fresh fruits and vegetables. J Food Sci 68(5): 1560-1565 (2003).

85. Ruiz-García Y, Gómez-Plaza E. Elicitors: a tool for improving fruit phenolic content. Agriculture 3(1), 33-52 (2013).

86. Vithana MD, Singh Z, Johnson SK. Cold storage temperatures and durations affect the concentrations of lupeol, mangiferin, phenolic acids and other healthpromoting compounds in the pulp and peel of ripe mango fruit. Postharvest Biol Technol 139: 91-98 (2018b).

87. Shivashankara KS, Isobe S, Al-Haq MI, Takenaka M, Shiina T. Fruit antioxidant activity, ascorbic acid, total phenol, quercetin, and carotene of 
Irwin mango fruits stored at low temperature after high electric field pretreatment. J Agric Food Chem 52(5): 1281-1286 (2004).

88. Robles-Sánchez RM, Islas-Osuna MA, Astiazarán-García H, Vázquez-Ortiz F A, Martín-Belloso O, Gorinstein S, González-Aguilar GA. Quality index, consumer acceptability, bioactive compounds, and antioxidant activity of fresh-cut "Ataulfo" mangoes (Mangifera indica L.) as affected by low-temperature storage. J Food Sci 74(3): S126-S134 (2009).

89. Kim Y, Lounds-Singleton AJ, Talcott ST. Antioxidant phytochemical and quality changes associated with hot water immersion treatment of mangoes (Mangifera indica L.). Food Chem 115(3): 989-993 (2009).

90. Raskin I, Ribnicky DM, Komarnytsky S, Ilic N, Poulev A, Borisjuk N, Brinker A, Moreno DA, Ripoll C, Yakobi N, O'Neal JM. Plants and human health in the twenty-first century. Trends Biotechnol 20(12): 522-531 (2002).

91. Haminiuk CW, Maciel GM, Plata-Oviedo MS, Peralta RM. Phenolic compounds in fruits-an overview. Int J Food Sci Technol 47(10): 2023-2044 (2012).

92. Seigler DS. Shikimic Acid Pathway. In Plant Secondary Metabolism, Springer, US. 94-105(1998). 
93. Tsao R. Chemistry and biochemistry of dietary polyphenols. Nutrients 2(12): 1231-1246 (2010).

94. McGarvey DJ, Croteau R. Terpenoid metabolism. Plant Cell 7(7): 1015 (1995).

95. Croteau R, Kutchan TM, Lewis NG. Natural products (secondary metabolites). Biochem Mol Biol Plants 24: 1250-1319 (2000).

96. Aharoni A, Jongsma MA, Bouwmeester HJ. Volatile science? metabolic engineering of terpenoids in plants. Trends Plant Sci 10(12): 594-602 (2005).

97. Lalel HJ, Singh Z, Tan SC. Maturity stage at harvest affects fruit ripening, quality and biosynthesis of aroma volatile compounds in 'Kensington Pride' mango. J Hort Sci Biotechnol 78(2): 225-233 (2003).

98. Mulabagal V, Tsay HS. Plant cell cultures-an alternative and efficient source for the production of biologically important secondary metabolites. Int J Appl Sci Eng 2(1): 29-48 (2004).

99. Zhao J, Davis LC, Verpoorte R. Elicitor signal transduction leading to production of plant secondary metabolites. Biotechnol Adv 23(4): 283-333 (2005).

This article is protected by copyright. All rights reserved. 
100. Gundlach H, Müller MJ, Kutchan TM, Zenk, MH. Jasmonic acid is a signal transducer in elicitor-induced plant cell cultures. Proc Natl Acad Sci 89(6): 2389-2393 (1992).

101. Jacobo-Velázquez DA, Cisneros-Zevallos L. An alternative use of horticultural crops: stressed plants as biofactories of bioactive phenolic compounds. Agriculture 2(3), 259-271 (2012).

102. Gonzalez-Aguilar GA, Fortiz J, Cruz R, Baez R, Wang CY. Methyl jasmonate reduces chilling injury and maintains postharvest quality of mango fruit. J agric food chem 48 (2):515-519 (2000).

103. González-Aguilar GA, Buta JG, Wang CY. Methyl jasmonate reduces chilling injury symptoms and enhances colour development of 'Kent'mangoes. J sci food agric 81(13):1244-1249 (2001).

104. Lalel HJ, Singh Z, Tan SC. The role of methyl jasmonate in mango ripening and biosynthesis of aroma volatile compounds. $J$ hortic sci biotech 78(4):470-484 (2003).

105. Joyce DC, Wearing H, Coates L, Terry L. Effects of phosphonate and salicylic acid treatments on anthracnose disease development and ripening of 'Kensington Pride' mango fruit. Aust j exp agric 41(6):805-813 (2001).

106. Zaharah SS, Singh Z. Postharvest nitric oxide fumigation alleviates chilling injury, delays fruit ripening and maintains quality in cold-stored ‘Kensington Pride’mango. Postharvest biol technol 60(3):202-10 (2011). 
107. Zeng K, Cao J, Jiang W. Enhancing disease resistance in harvested mango (Mangifera indica L. cv.'Matisu') fruit by salicylic acid. $J$ sci food agric 86(5):694-698 (2006).

108. Barman K, Asrey R. Salicylic acid pre-treatment alleviates chilling injury, preserves bioactive compounds and enhances shelf life of mango fruit during cold storage. $J$ sci ind res 73: 713-718. (2014).

109. Vithana MD, Singh Z, Johnson SK, Gupta, R. Concentrations of healthpromoting phytochemicals in ripe mango fruit triggered by postharvest application of elicitors $J$ Sci Food Agric (Accepted article), DOI: 10.1002/jsfa.9280 (2018c).

110. Fischbach RJ, Zimmer I, Steinbrecher R, Pfichner A, Schnitzler JP. Monoterpene synthase activities in leaves of Picea abies (L.) Karst. and Quercus ilex L. Phytochemistry 54(3): 257-265 (2000).

111. Vithana MD, Singh Z, Johnson S K. Levels of terpenoids, mangiferin and phenolic acids in the pulp and peel of ripe mango fruit influenced by preharvest application of FeSO4 $\left(\mathrm{Fe}^{2+}\right), \mathrm{MgSO} 4\left(\mathrm{Mg}^{2+}\right)$ and $\mathrm{MnSO} 4\left(\mathrm{Mn}^{2+}\right)$. Food Chem. 256, 71-76 (2018d).

This article is protected by copyright. All rights reserved. 